Cleaner Production

Elsevier Editorial System(tm) for Journal of

Manuscript Draft

Manuscript Number: JCLEPRO-D-19-07060R3

Title: Municipal solid waste incineration bottom ash as Alkali-Activated Cement precursor depending on particle size

Article Type: Original article

Keywords: Bottom Ash; Waste Management; Alkali Activated Cement; Cement precursor

Corresponding Author: Dr. Josep Maria Ma. Chimenos, Ph.D.

Corresponding Author's Institution: University of Barcelona

First Author: Àlex Maldonado-Alameda

Order of Authors: Àlex Maldonado-Alameda; Jessica Giro-Paloma; Adela Svobodova-Sedlackova; Joan Formosa; Josep Maria Ma. Chimenos, Ph.D.

Abstract: Bottom Ash (BA) is the main by-product of municipal solid waste incineration (MSWI). It is stabilised outdoors to obtain weathered bottom ash (WBA) whose main application is in the construction sector as a secondary aggregate for road sub-base. Here, the aim of this work is to advance the study of the potential use of WBA as a precursor in the synthesis of new alkali-activated cements (AACs). An exhaustive physicochemical characterisation (X-ray fluorescence, X-ray diffraction, Fourier-transform infrared spectroscopy, inductively coupled plasma optical emission spectroscopy, and Inductively coupled plasma - mass spectroscopy) of WBA was provided depending on its particle size $(<30$, 30-16, 16-8, 8-4, 4-2 and 2-0 mm). The study reveals that WBA is composed mainly of the essential reactive phases to form AACs, which are Sio2, Al203, and CaO. It is demonstrated the larger the particle size, the higher the content of SiO2; and the smaller the particle size, the higher the heavy metal(loid) content. The availability of reactive phases was analysed through chemical attacks with $\mathrm{HF}$ and $\mathrm{NaOH}$ solutions of different concentrations $(2 \mathrm{M}, 4 \mathrm{M}$, and $8 \mathrm{M})$. The results demonstrate the availability of reactive phases (including 150 to $250 \mathrm{~g} \cdot \mathrm{kg}-1$ of $\mathrm{SiO} 2$ and 50 to 65 $\mathrm{g} \cdot \mathrm{kg}-1$ of Al203) in all the particle size fractions studied. WBA potential will be of considerable use to formulate AACs, depending on the particle size fraction and the Si/Al ratio, both as the sole precursor and mixed with others. 


\title{
Title: Municipal solid waste incineration bottom ash as Alkali-Activated Cement precursor depending on particle size
}

\author{
Authors: A. Maldonado-Alameda, J. Giro-Paloma, A. Svobodova-Sedlackova, \\ J. Formosa, J.M. Chimenos
}

The responses to editor suggestions are presented below. Hopefully, we answered all the questions and clarified all issues. Enclosed, please find the revised manuscript.

\section{Answers to the Editor suggestions}

Is it possible to remove 'as a function of particle size in the title? It will look better and looks like a title rather than a sentence.

Thank you for the suggestion. The authors think that the part 'as a function of particle size' provide relevant information for the potential readers. However, the title has been modified to looks like a title.

Please remove those redundant words, e.g. Additionally, etc.

The redundant words were removed.

Please make the Conclusions more concise, of about 1-2 paragraph to only underscore the key results and how it contributes to the future work.

The conclusions have been changed. Now, they are more concise underscore the key results and to emphasise the future work. 
Municipal solid waste incineration bottom ash as AlkaliActivated Cement precursor depending on particle size

A. Maldonado-Alameda ${ }^{\text {a }}$, J. Giro-Paloma ${ }^{\text {a }}$, A. Svobodova-Sedlackova ${ }^{\text {a }}$, J. Formosa ${ }^{\text {a }}$, J.M. Chimenos ${ }^{\text {a, * }}$

a Departament de Ciència de Materials i Química Física, Universitat de Barcelona, C/ Martí i Franquès, 1, 08028, Barcelona, Spain. 


\section{Highlights}

$>$ Weathered bottom ash (WBA) potential as alkali-activation material has been evaluated.

$\mathrm{SiO}_{2}, \mathrm{Al}_{2} \mathrm{O}_{3}$, and $\mathrm{CaO}$ are the main components of $\mathrm{WBA}$.

The availability of $\mathrm{SiO}_{2}$ and $\mathrm{Al}_{2} \mathrm{O}_{3}$ is high in the coarser fractions of WBA.

After $\mathrm{NaOH} 8 \mathrm{M}$ chemical attack, metal(loid)s content is high in the finest fractions. 


\title{
Municipal solid waste incineration bottom ash as Alkali-Activated Cement precursor depending on particle size
}

\author{
A. Maldonado-Alameda ${ }^{\text {a }, ~ J . ~ G i r o-P a l o m a ~}{ }^{\text {a }, ~ A . ~ S v o b o d o v a-S e d l a c k o v a ~}{ }^{\text {a }, ~ J . ~ F o r m o s a ~}{ }^{\text {a }}$, \\ J.M. Chimenos ${ }^{\text {a, * }}$ \\ a Departament de Ciència de Materials i Química Física, Universitat de Barcelona, C/ Martí i Franquès, 1, 08028, \\ Barcelona, Spain.
}




\begin{abstract}
Bottom Ash (BA) is the main by-product of municipal solid waste incineration (MSWI). It is stabilised outdoors to obtain weathered bottom ash (WBA) whose main application is in the construction sector as a secondary aggregate for road sub-base. Here, the aim of this work is to advance the study of the potential use of WBA as a precursor in the synthesis of new alkaliactivated cements (AACs). An exhaustive physicochemical characterisation (X-ray fluorescence, X-ray diffraction, Fourier-transform infrared spectroscopy, inductively coupled plasma - optical emission spectroscopy, and Inductively coupled plasma - mass spectroscopy) of WBA was provided depending on its particle size $(<30,30-16,16-8,8-4,4-2$ and 2-0 mm). The study reveals that WBA is composed mainly of the essential reactive phases to form AACs, which are $\mathrm{SiO}_{2}, \mathrm{Al}_{2} \mathrm{O}_{3}$, and $\mathrm{CaO}$. It is demonstrated the larger the particle size, the higher the content of $\mathrm{SiO}_{2}$; and the smaller the particle size, the higher the heavy metal(loid) content. The availability of reactive phases was analysed through chemical attacks with $\mathrm{HF}$ and $\mathrm{NaOH}$ solutions of different concentrations $(2 \mathrm{M}, 4 \mathrm{M}$, and $8 \mathrm{M})$. The results demonstrate the availability of reactive phases (including 150 to $250 \mathrm{~g} \cdot \mathrm{kg}^{-1}$ of $\mathrm{SiO}_{2}$ and 50 to $65 \mathrm{~g} \cdot \mathrm{kg}^{-1}$ of $\mathrm{Al}_{2} \mathrm{O}_{3}$ ) in all the particle size fractions studied. WBA potential will be of considerable use to formulate AACs, depending on the particle size fraction and the $\mathrm{Si} / \mathrm{Al}$ ratio, both as the sole precursor and mixed with others.
\end{abstract}

Keywords: Bottom Ash, Waste Management, Alkali Activated Cement, Cement precursor 


\section{Introduction}

The Waste Framework Directive (European Parliament and Council, 2008) of the European Parliament and the policies of the member states of the European Union (EU) focus on maintaining the value of products, materials and resources for as long as possible, moving towards a circular economy (European Commission, 2017). The priority of the member states is to continue promoting and developing systems and infrastructures that provide proper municipal solid waste (MSW) management. According to the EU waste management hierarchy (European Parliament and Council, 2008), landfilling is the least preferable option, and its use is expected to be limited to as little as $10 \%$ by the year 2030 (European Commision, 2015). The EU order of priority establishes prevention, reuse, and recycling as the main processes in MSW management. However, one of the most suitable alternatives to landfilling for MSW is energy recovery in waste-to-energy (WtE) plants, which contribute to reducing the volume (up to $90 \%$ ) and weight (up to $75 \%$ ) of municipal waste (MW) (Cheng and $\mathrm{Hu}, 2010)$.

Incineration bottom ash (IBA) is the main by-product of the combustion process in WtE plants (Chimenos et al., 1999). Around $18 \mathrm{Mt} \cdot \mathrm{y}^{-1}$ of IBA is produced in the EU (CEWEP, 2016). This MSW incineration (MSWI) residue, which is approximately $85 \%$ of the solid resulting from combustion, can be considered as slag, granular material, and non-hazardous waste (Valle-zermeño et al., 2017). IBA is mainly composed of silicon, calcium, iron, aluminium, and sodium, although it also contains small amounts of several heavy metal(loid)s. For its subsequent reuse as a secondary material, a weathering (aging) process lasting 2-3 months is necessary, during which the IBA is stored outdoors. This procedure results in carbonation and oxidation of the IBA and its consequent $\mathrm{pH}$ stabilisation with 
values between 8 to 10, as well as the neo-formation and hydration of mineral phases, among other consequences (Chimenos et al., 2000). The material resulting from the weathering process is known as weathered bottom ash (WBA). Approximately $85 \%$ of WBA is glass, ceramics, stone, brick, concrete, ash, and melting products, which has a grain size distribution and technical properties that are similar to those of natural sand and gravel (Zhang and Shimaoka, 2013). The potential applications of the WBA are plenty and assorted. In many countries like France, Italy, the Netherlands or China, there is a great interest in valorising WBA. During the last years several studies have been carried out in some sectors. In the field of civil engineering as secondary aggregate for road construction (Cioffi et al., 2011; Hjelmar et al., 2007), embankments (Pecqueur et al., 2001), and pavements (Toraldo et al., 2013), as well as concrete filling (Ginés et al., 2009). Regarding the building sector it is studied its application as ceramic material such as tiles, bricks and glass-ceramics (Lancellotti et al., 2014). In the chemical engineering field, studies have been carried out for its use as an absorbent for wastewater treatment processes (Shim et al., 2003) as well as co-disposal and biogas production (Silva et al., 2017).

Besides the concerns regarding waste management, the cement industry can also present a threat to the environment (Aljerf, 2015). Cement production is responsible for some 5\%-7\% of $\mathrm{CO}_{2}$ emissions worldwide (McLellan et al., 2011) and it is estimated to consume $2 \%$ of global primary energy (Chen, 2009). The cement industry must face the challenge of finding new processes to manufacture in a more ecological and respectful way, reducing energy consumption and greenhouse gas emissions. The use of by-products such as WBA to manufacture cementitious materials could be one way to obtain eco-friendly cements. Fullscale demonstrations of the technical feasibility of unbound and cement-bound sub-base layers containing WBA, i.e. general ceramics, glass or glass-ceramics, have been successful (Arm, 2003; Magnusson, 2005). Alkali-activated cements (AACs) have become an ideal 
alternative to ordinary Portland cement (OPC) because of their properties. AACs have good compression strength (Alonso et al., 2000), high resistance to chemical attack by aggressive aqueous and acid solutions (Bakharev, 2005), and resistance to fire and high temperature (Murri et al., 2013). However, the main benefit exhibited by AACs is their greater respect for the environment, compared to other cementitious materials. If AACs are compared to OPC, the former reduces the $\mathrm{CO}_{2}$ emissions and the energy consumption associated with cement manufacture (Van Deventer et al., 2012). It is important to highlight that AACs, as most of the new cements produced using industrial by-products or waste (Bernal et al., 2016), follow the zero waste principle (Komnitsas, 2011). For this reason, AACs are considered new sustainable and eco-friendly cements (Phair, 2006). The alkaline activation reaction is a polycondensation which starts when a solid powder precursor (based on alumino-silicates) is dissolved in an alkaline medium. This reaction generates free silica tetrahedral and aluminium cations coordinated with oxygen, which will form a 3D structure (Duxson et al., 2007; Singh et al., 2015). The final AACs properties depend on the precursor, the relation between the proportions of $\mathrm{SiO}_{2}$ and $\mathrm{Al}_{2} \mathrm{O}_{3}$, the $\mathrm{CaO}$ content, the alkali activator used, and the curing temperature (Aljerf, 2015).

Previous studies have revealed that WBA is mainly composed of $\mathrm{SiO}_{2}, \mathrm{Al}_{2} \mathrm{O}_{3}$, and $\mathrm{CaO}$ (Valle-zermeño et al., 2017; Wei et al., 2011), which are the essential mineral phases required to formulate AACs. WBA contains enough glassy materials (primary or secondary glass) (Valle-zermeño et al., 2017), as well as important amounts of both sources of aluminium and calcium for its use as a precursor in the formulation of AACs. However, WBA presents a high heterogeneity and its composition varies depending on particle size fraction (Valle-zermeño et al., 2017). The availability of reactive phases $\left(\mathrm{SiO}_{2}\right.$ and $\left.\mathrm{Al}_{2} \mathrm{O}_{3}\right)$ in each fraction will vary as a function of the composition and the alkali activator concentration. Physicochemical characterisation and determination of $\mathrm{SiO}_{2}$ and $\mathrm{Al}_{2} \mathrm{O}_{3}$ availability will allow to determine the 
possibilities of using a specific WBA particle size as the sole precursor in the synthesis of $\mathrm{SiO}_{2} / \mathrm{Al}_{2} \mathrm{O}_{3}$ ratio.(Aljerf, 2015).

In this research, the main goal is to determine the added value of WBA as precursor in AACs formulation to contribute to the EU's objectives in the waste management and valorisation fields. This work focuses on the determination of $\mathrm{SiO}_{2}$ and $\mathrm{Al}_{2} \mathrm{O}_{3}$ available in WBA, as the reactive phases required to formulate new AACs, as a function of WBA particle size. The availability of these reactive phases in each fraction is analysed through chemical attacks, and it is related to the amorphous phases content, as well as with the material characterisation determined elsewhere (Chimenos et al., 1999; Valle-zermeño et al., 2017). For each particle size fraction of WBA under study, it is analysed the concentration of heavy metals and metal(loid)s leached during the alkaline activation of reactive phases to determine the potential release of WBA used as a precursor in the formulation of AACs.

\section{Experimental procedure}

\subsection{Materials}

The WBA sample was supplied by the company Valorización de Escorias para la Construcción S.A. (VECSA), which is responsible for valorising and commercialising the IBA collected from the WtE plant located in Tarragona (Spain). The feed stream treated in the incineration plant $\left(140 \mathrm{kt} \cdot \mathrm{y}^{-1}\right)$ is mainly composed of household rubbish with a small input from commercial sources. The incineration temperature is around $950^{\circ} \mathrm{C}$ (Chimenos et al., 1999). Approximately, $32 \mathrm{kt} \cdot \mathrm{y}^{-1}$ of fresh IBA is produced by the incineration plant annually and treated to recover both ferrous and non-ferrous metals, as well as the lightweight materials that can be removed. After being conditioned, the resultant IBA is stockpiled outdoors for at least three months, to ensure immobilisation of heavy metal(loid)s by weathering and to obtain WBA. Due to the heterogeneity of IBA, for this study around $100 \mathrm{~kg}$ 
of WBA was collected from various stockpiles, homogenised, and stored in a $30 \mathrm{~L}$ plastic

\subsection{Samples preparation}

The samples preparation scheme is shown in Fig. 1. First, the WBA was dried overnight at $105^{\circ} \mathrm{C}$ in a stove. Then, the particle size distribution (PSD) was analysed by sieving the dried WBA through openings standards of 2, 4, 8 and $16 \mathrm{~mm}$ (Valle-zermeño et al., 2017). After sieving, around $100 \mathrm{~g}$ of each fraction $(<30,30-16,16-8,8-4,4-2$ and $2-0 \mathrm{~mm})$ was initially quartered and crushed in a jaw crusher. The samples were milled in a vibratory disc mill, using a grinding set made of hardened steel. It is important to highlight that the $<30 \mathrm{~mm}$ fraction corresponds to the bulk sample without being sieved. The milling continued until the whole sample passed through a sieve of $80 \mu \mathrm{m}$ mesh (except for the ferrous and non-ferrous metal particles which, due to their ductility, were retained in the sieves) resulting in a homogeneous powder. A magnet $(\mathrm{Nd} ; 0.485 \mathrm{~T})$ was passed over the sample to remove magnetic particles.

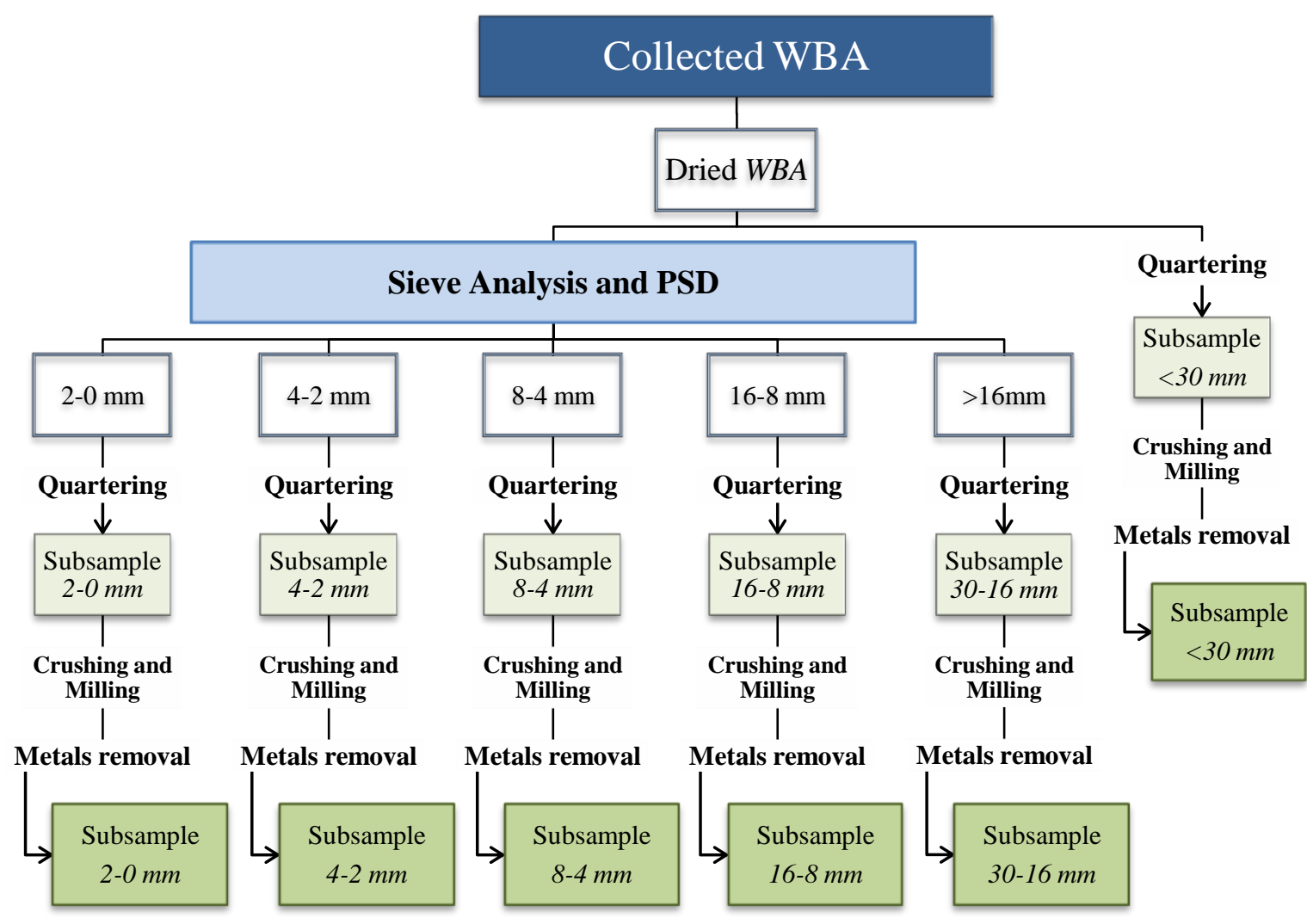


Fig. 1. Scheme of the preparation of samples.

\subsection{WBA Characterization}

\subsubsection{Physicochemical characterization}

For each powdered size fraction of the WBA, the chemical composition of the major and minor elements was determined by means of X-ray fluorescence spectroscopy (XRF) using a Panalytical Philips PW 2400 sequential X-ray spectrometer with UniQuant ${ }^{\circledR}$ V5.0 software.

The mineral and crystalline phases of the powdered WBA fractions were identified by Xray diffraction analysis (XRD) using a Bragg-Brentano Siemens D-500 powder diffractometer with $\mathrm{CuK} \alpha$ radiation. The amorphous index for samples containing both amorphous and crystalline phases was quantified with the external standard method (Jansen et al., 2011; Snellings et al., 2014).

\subsection{2. $\mathrm{SiO}_{2}$ and $\mathrm{Al}_{2} \mathrm{O}_{3}$ availability}

The availability of reactive phases $\left(\mathrm{SiO}_{2}\right.$ and $\left.\mathrm{Al}_{2} \mathrm{O}_{3}\right)$ was determined through chemical attacks with $\mathrm{HF}(1 \% \mathrm{v} / \mathrm{v})$ and $\mathrm{NaOH}$ solutions (2M, 4M, and 8M) (Aljerf, 2015; RuizSantaquiteria et al., 2011). For these experimental trials, one gram of WBA sample was mixed with $100 \mathrm{~mL}$ of each activating solution and stirred constantly for $5 \mathrm{~h}$ in a sealed plastic container, at $80^{\circ} \mathrm{C}$ for alkaline solutions, or at room temperature in the case of $\mathrm{HF}$. The resulting solution was filtered and analysed by means of inductively coupled plasma optical emission spectrometry (ICP-OES) using Perkin Elmer Optima ICP-OES 3200 RL equipment to quantify the Si and Al leached (Ruiz-Santaquiteria et al., 2011). It was used Fouriertransform infrared spectroscopy by attenuated total reflection (FT-IR ATR) to evaluate the chemical structure and composition and compared both the initial and attacked WBA powders (with $\mathrm{HF}$ and the different $\mathrm{NaOH}$ solutions) using Spectrum $\mathrm{Two}^{\mathrm{TM}}$ equipment from Perkin Elmer.

\subsubsection{Heavy metals content}


The potential environmental impact of the WBA was assessed by analysing the heavy metal(loid)s released in the filtered $\mathrm{NaOH} 8 \mathrm{M}$ solutions during the alkaline activation using a Perkin Elmer ELAN 6000 ICP mass spectrometry (ICP-MS) device.

\section{Results and discussion}

\subsection{WBA Characterization}

\subsubsection{Physicochemical characterization}

Fig. 2 shows the PSD of the WBA. Around $50 \%$ of the WBA corresponds to fractions below $4 \mathrm{~mm}$ (fine fraction), in agreement with previous findings (Chimenos et al., 1999; Valle-zermeño et al., 2017).

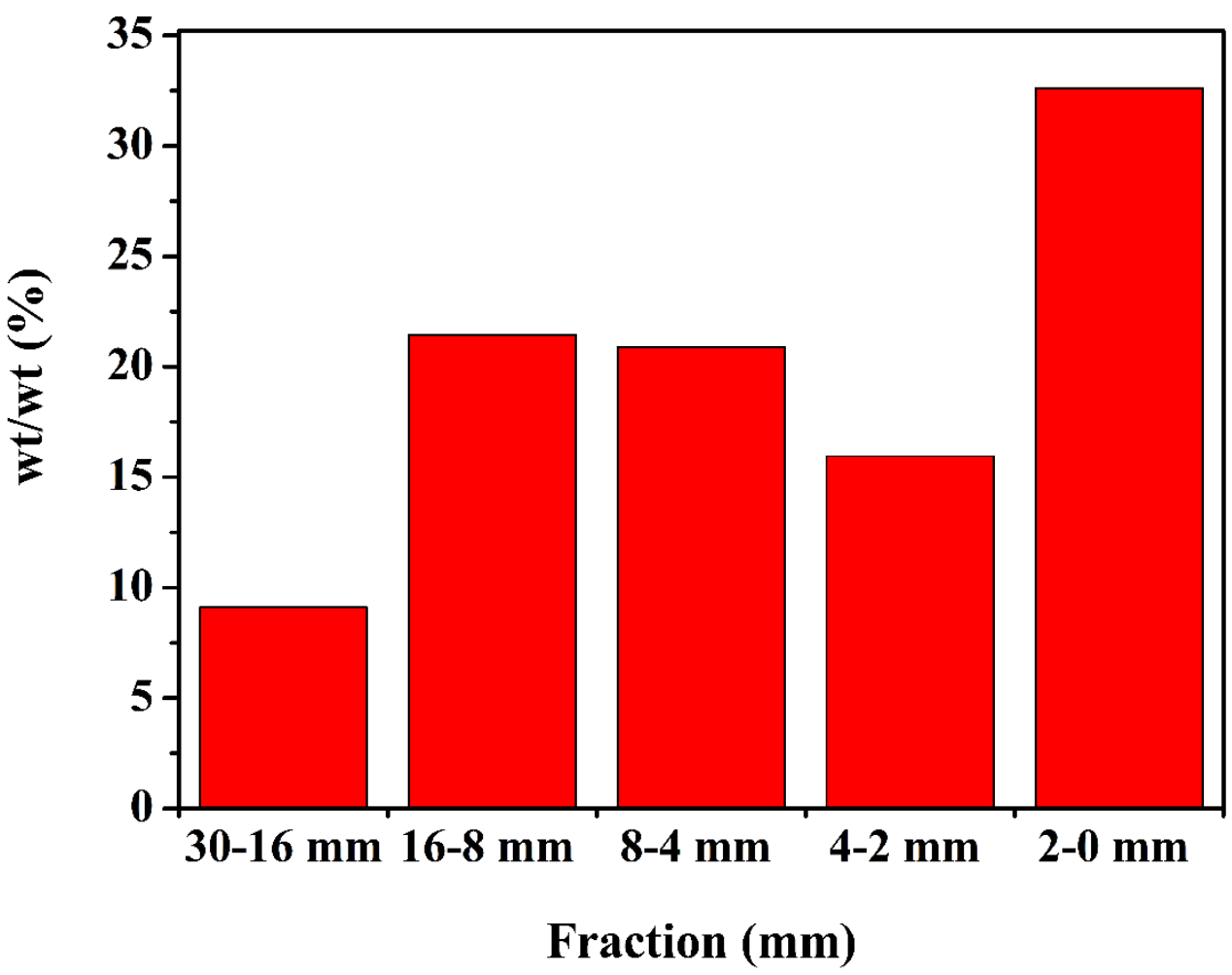

Fig. 2. Particle Size Distribution of Weathered Bottom Ash

The major and minor elemental composition, as elemental oxides and trace-elements in each size fraction of WBA analysed, are given in Table 1 . As expected, the most abundant oxides were $\mathrm{SiO}_{2}, \mathrm{CaO}$, and $\mathrm{Al}_{2} \mathrm{O}_{3}$, which are the key compounds in cementitious materials 
(Aljerf, 2015; Roy, 1999). As can be seen, the contents of these oxides varied, depending on the size fraction. The highest $\mathrm{SiO}_{2}$ content was in coarse fractions $(30-16,16-8$, and 8-4 mm) due to the primary and secondary glass present, as well as the synthetic ceramic materials present in these fractions (Chimenos et al., 2003; Valle-zermeño et al., 2017). As for $\mathrm{Al}_{2} \mathrm{O}_{3}$, its content trends to increase as the particle size decreases, except for the 30-16 mm fraction. This is due to the Eddy current device, because only recovers the non-ferrous fraction from the particle size fractions greater $10 \mathrm{~mm}$. Moreover, the $30-16 \mathrm{~mm}$ size fraction contains a large amount of synthetic ceramics (Valle-zermeño et al., 2017). The high content of $\mathrm{CaO}$ in the finest fractions (4-2 and 2-0 mm) is due to the presence of large amounts of calcium carbonates that are neo-formed during the weathering process of portlandite (Chimenos et al., 2003). This $\mathrm{CaO}$ high amount is also because of the presence of cementitious materials, based on OPC, and synthetic ceramics from small domestic works. These materials are fragmented by mechanical attrition and thermal shock inside the combustion furnaces (Aljerf, 2015). It is important to note that the major and minor element contents of the $<30 \mathrm{~mm}$ fraction agree with the contents calculated from the XRF results and the PSD weighting for each fraction (Fig. 2).

Table 1. Major-, minor- and trace-elements for each size fraction of WBA.

\begin{tabular}{|c|c|c|c|c|c|c|}
\hline & \multicolumn{6}{|c|}{ (wt. \%) } \\
\hline & 2-0 $\mathrm{mm}$ & 4-2 $\mathrm{mm}$ & 8-4 mm & $16-8 \mathrm{~mm}$ & $30-16 \mathrm{~mm}$ & $<30 \mathrm{~mm}$ \\
\hline $\mathrm{SiO}_{2}$ & 25.11 & 39.02 & 54.45 & 59.3 & 50.23 & 45.44 \\
\hline $\mathrm{CaO}$ & 23.77 & 19.35 & 15.15 & 13.6 & 16.25 & 17.55 \\
\hline $\mathbf{A l}_{2} \mathbf{O}_{3}$ & 11.19 & 9.62 & 7.32 & 6.74 & 12.39 & 10.38 \\
\hline $\mathrm{Na}_{2} \mathrm{O}$ & 2.78 & 4.93 & 8.14 & 7.77 & 3.11 & 5.04 \\
\hline $\mathbf{K}_{2} \mathbf{O}$ & 1.11 & 1.41 & 1.25 & 1.61 & 1.95 & 1.54 \\
\hline $\mathrm{Fe}_{2} \mathrm{O}_{3}$ & 7.22 & 6.89 & 5.43 & 4.19 & 3.49 & 6.08 \\
\hline MgO & 2.88 & 3.24 & 1.99 & 2.30 & 2.74 & 2.66 \\
\hline $\mathrm{TiO}_{2}$ & 0.82 & 0.67 & 0.44 & 0.37 & 0.56 & 0.65 \\
\hline $\mathrm{Cl}^{-}$ & 1.99 & 1.14 & 0.62 & 0.40 & 0.93 & 1.42 \\
\hline $\mathrm{SO}_{3}$ & 3.57 & 1.59 & 0.96 & 0.63 & 2.27 & 2.57 \\
\hline Mn & 0.05 & 0.03 & 0.03 & 0.02 & 0.02 & 0.03 \\
\hline $\mathbf{C u}$ & 0.18 & 0.13 & 0.10 & 0.04 & 0.04 & 0.13 \\
\hline Zn & 0.73 & 0.39 & 0.64 & 0.09 & 0.18 & 0.51 \\
\hline $\mathrm{Br}$ & $<0.01$ & $<0.01$ & $<0.01$ & $<0.01$ & $<0.01$ & $<0.01$ \\
\hline
\end{tabular}




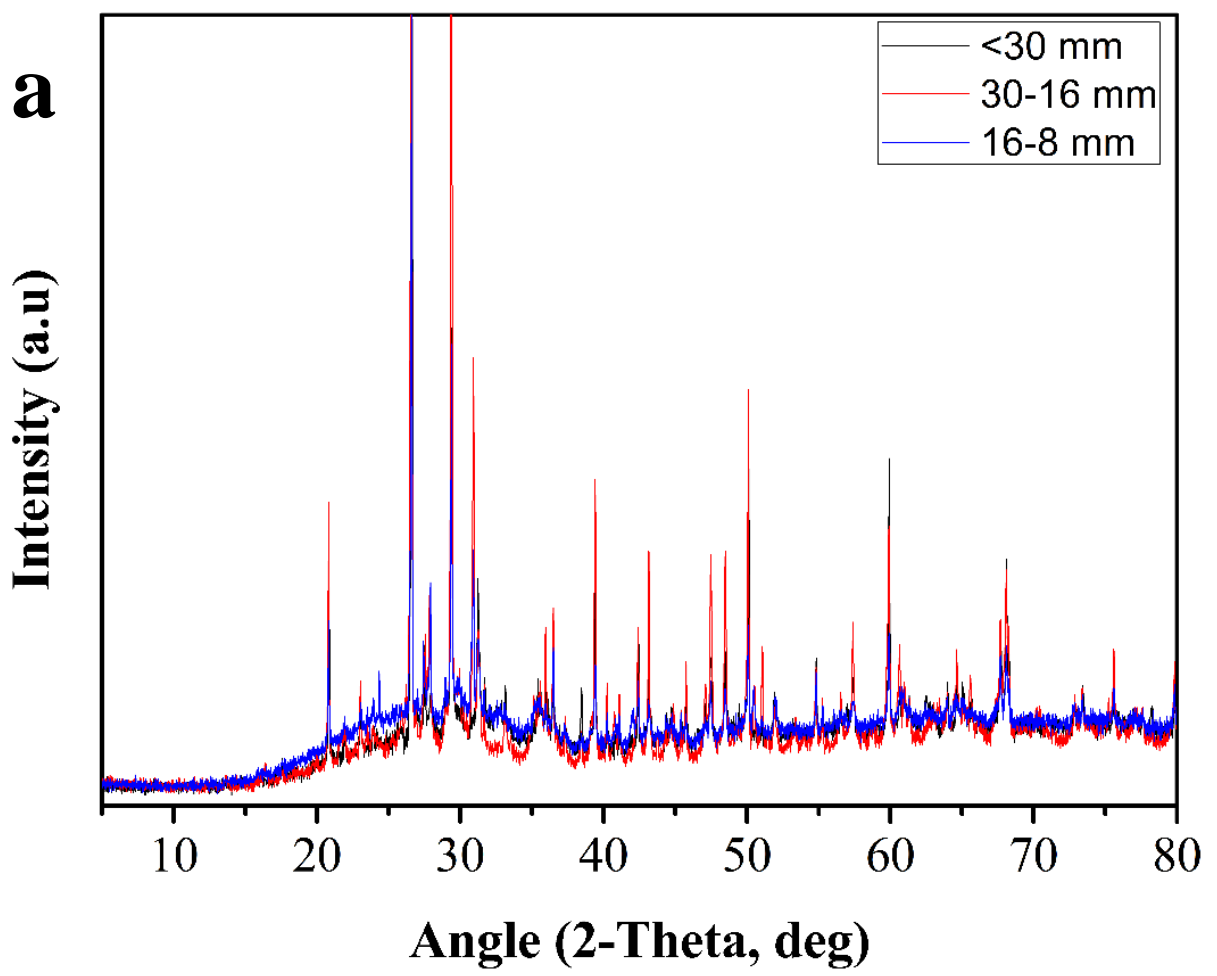




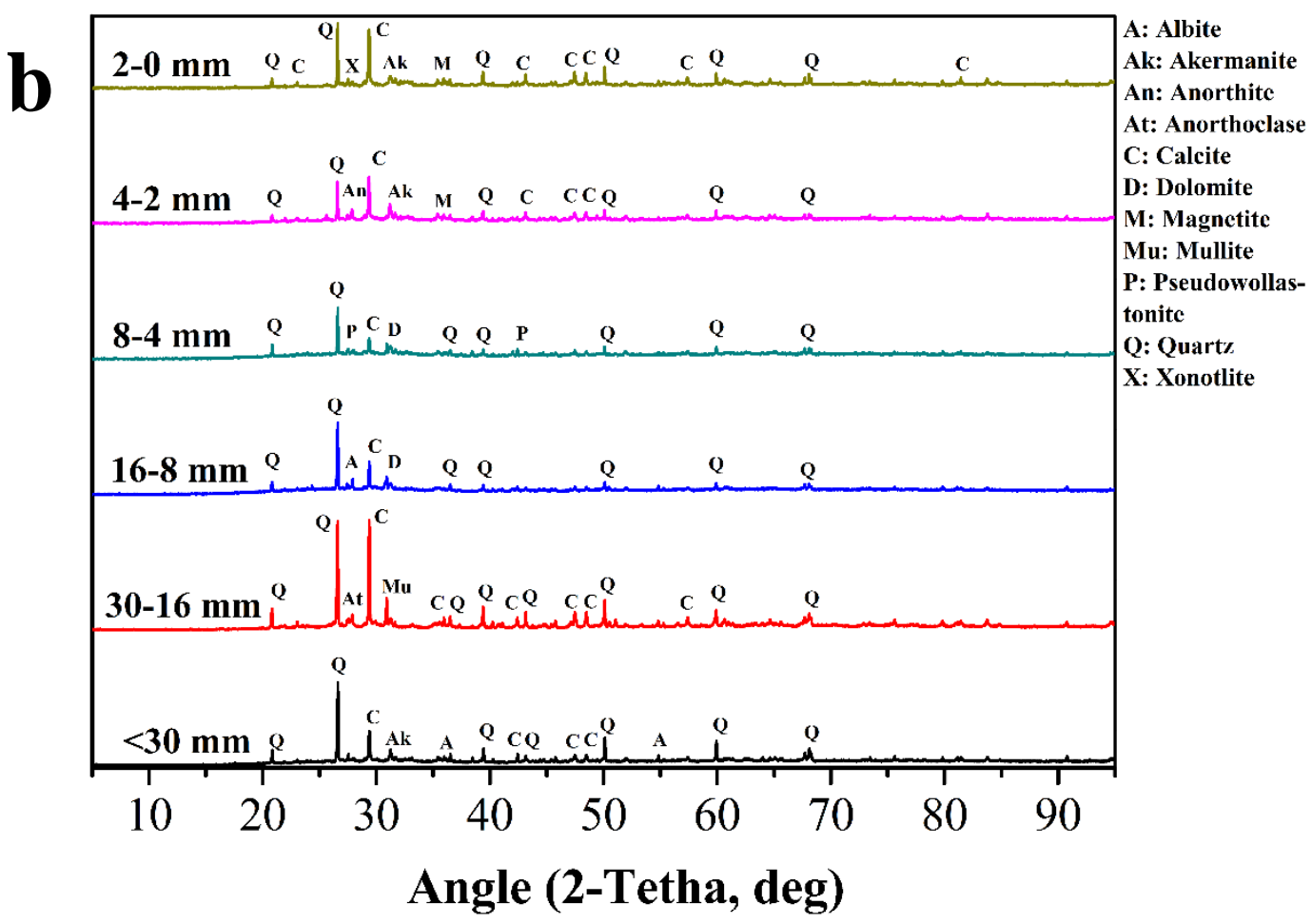

Fig. 3. (a) XRD patterns of $<30,30-16$, and $16-8 \mathrm{~mm}$ fractions (b) Dominant peaks of XRD patterns of all samples

The main crystalline phases determined, depending on the size fraction, are shown in Table 2. The mineralogical compositions are similar, being the phases rich in $\mathrm{Si}, \mathrm{Al}$ and $\mathrm{Ca}$ (quartz, calcite, albite, dolomite, etc.) more abundant. It is important to highlight the presence of metallic phases in the finest fractions $(<30,4-2$ and $2-0 \mathrm{~mm})$ and the great variety of silicoaluminate phases in all the fractions while being more abundant in coarse fractions.

Table 2. Major crystalline phases in WBA samples.

\begin{tabular}{|c|c|c|c|c|c|c|}
\hline \multirow{2}{*}{ Mineral Phase } & \multicolumn{6}{|c|}{ Fraction } \\
\hline & 2-0 $\mathrm{mm}$ & 4-2 mm & 8-4 mm & $16-8 \mathrm{~mm}$ & 30-16 mm & $<30 \mathrm{~mm}$ \\
\hline Albite $\left(\mathrm{NaAlSi}_{3} \mathrm{O}_{8}\right)$ & & & $\checkmark$ & $\checkmark$ & $\checkmark$ & $\checkmark$ \\
\hline $\begin{array}{c}\text { Akermanite } \\
\left(\mathrm{Ca}_{2} \mathrm{MgSi}_{2} \mathrm{O}_{7}\right)\end{array}$ & $\checkmark$ & $\checkmark$ & $\checkmark$ & & $\checkmark$ & $\checkmark$ \\
\hline Aluminium (Al) & & & $\checkmark$ & & & $\checkmark$ \\
\hline Anorthite $\left(\mathrm{CaAl}_{2} \mathrm{Si}_{2} \mathrm{O}_{8}\right)$ & & $\checkmark$ & & & & \\
\hline Anorthoclase & & & & & $\checkmark$ & \\
\hline
\end{tabular}




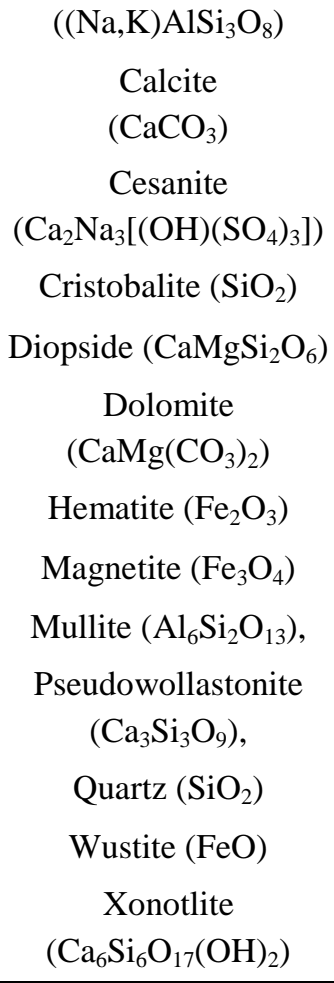

From the XRD patterns of each size fraction, the amorphous phases of the samples were quantified (Jansen et al., 2011; Snellings et al., 2014). Due to their abundance, quartz and amorphous glass samples were used as external patterns for this quantification. First, the crystalline compound was determined and then the amorphous phases were derived by differences, in the main angular range from $5^{\circ}$ to $80^{\circ}(2 \theta)$. The results are shown in Table 3 , where the amorphous index of the particle size fractions was $44 \%-70 \%$. As expected, the $30-$ $16,4-2$, and 2-0 mm size fractions presented the lowest amorphous index because of their high content in synthetic ceramics and metal compounds, in contrast to the rest of the fractions where the amorphous amount is around or above $60 \%$. It is important to highlight that the amorphous index of the $<30 \mathrm{~mm}$ is in agreement with that calculated using the external standard method and the PSD weighting of each fraction (Fig. 2).

Table 3. Amorphous content (wt.\%) in the size fractions of WBA.

\begin{tabular}{cc}
\hline $\begin{array}{c}\text { Size } \\
\text { Fractions }\end{array}$ & Amorphous content (wt.\%) \\
\hline$<\mathbf{3 0} \mathbf{~ m m}$ & 60 \\
\hline $\begin{array}{c}\mathbf{3 0 - 1 6} \\
\mathbf{m m}\end{array}$ & 44 \\
\hline
\end{tabular}




\begin{tabular}{ll}
\hline $\mathbf{1 6 - 8} \mathbf{~ m m}$ & 66 \\
\hline $\mathbf{8 - 4} \mathbf{~ m m}$ & 70 \\
\hline $\mathbf{4 - 2} \mathbf{~ m m}$ & 53 \\
\hline $\mathbf{2 - 0} \mathbf{~ m m}$ & 49 \\
\hline
\end{tabular}

\subsection{2. $\mathrm{SiO}_{2}$ and $\mathrm{Al}_{2} \mathrm{O}_{3}$ availability}

XRF and XRD results show a large content of silico-aluminate phases and amorphous phases, but not all of these are available to react with the activating solution and form AACs. In fact, although thermodynamics allows certain reaction mechanisms, the chemical kinetics shows that some of these require very long reaction times that cannot be assumed. It is known that the crystalline phases are far less reactive than the amorphous phases, and that the active surface of the particles and their size. The reaction temperature and the concentration of the activators, are some of the important parameters for activation of the reactive phases (RuizSantaquiteria et al., 2011). Accordingly, for each WBA particle size fraction, a chemical attack test was performed to determine the real amount $\left(\mathrm{g} \cdot \mathrm{kg}^{-1}\right.$ of WBA) of $\mathrm{SiO}_{2}$ and $\mathrm{Al}_{2} \mathrm{O}_{3}$ available to form AACs. It is expected that most of the $\mathrm{SiO}_{2}$ and $\mathrm{Al}_{2} \mathrm{O}_{3}$ available come from the amorphous phases. To a greater or lesser extent, all the particle size fractions contain $\mathrm{SiO}_{2}$ and $\mathrm{Al}_{2} \mathrm{O}_{3}$ amorphous phases, as shown in Figs. 4 to 6.

Focusing on the $\mathrm{NaOH}$ chemical attacks as a function of WBA particle size fraction, Fig. 4 shows that there is a broad trend (except for 8-4 and 16-8 $\mathrm{mm}$ ) to increase $\mathrm{SiO}_{2}$ availability as the $\mathrm{NaOH}$ concentration increases. This tendency is due to the highly aggressive chemical attack (from $2 \mathrm{M}$ to $8 \mathrm{M}$ ). Moreover, if it is compared the trend for all the fractions as a function of chemical attack, the same curve results in all cases and the maximum value was for the 16-8 mm fraction. Analysing the $\mathrm{SiO}_{2}$ availability of each fraction with the primary and secondary glass results obtained in a previous study (Valle-zermeño et al., 2017), validates this trend, except for the results in the $30-16 \mathrm{~mm}$ fraction. In this last case, the $\mathrm{SiO}_{2}$ extracted with chemical attacks comes from the synthetic ceramics. It is important to highlight 
that the $\mathrm{HF}$ attack indicated the existence of a large amount of available $\mathrm{SiO}_{2}$ amorphous phases that were not extracted with the $\mathrm{NaOH}$ chemical attacks, since they are less aggressive.

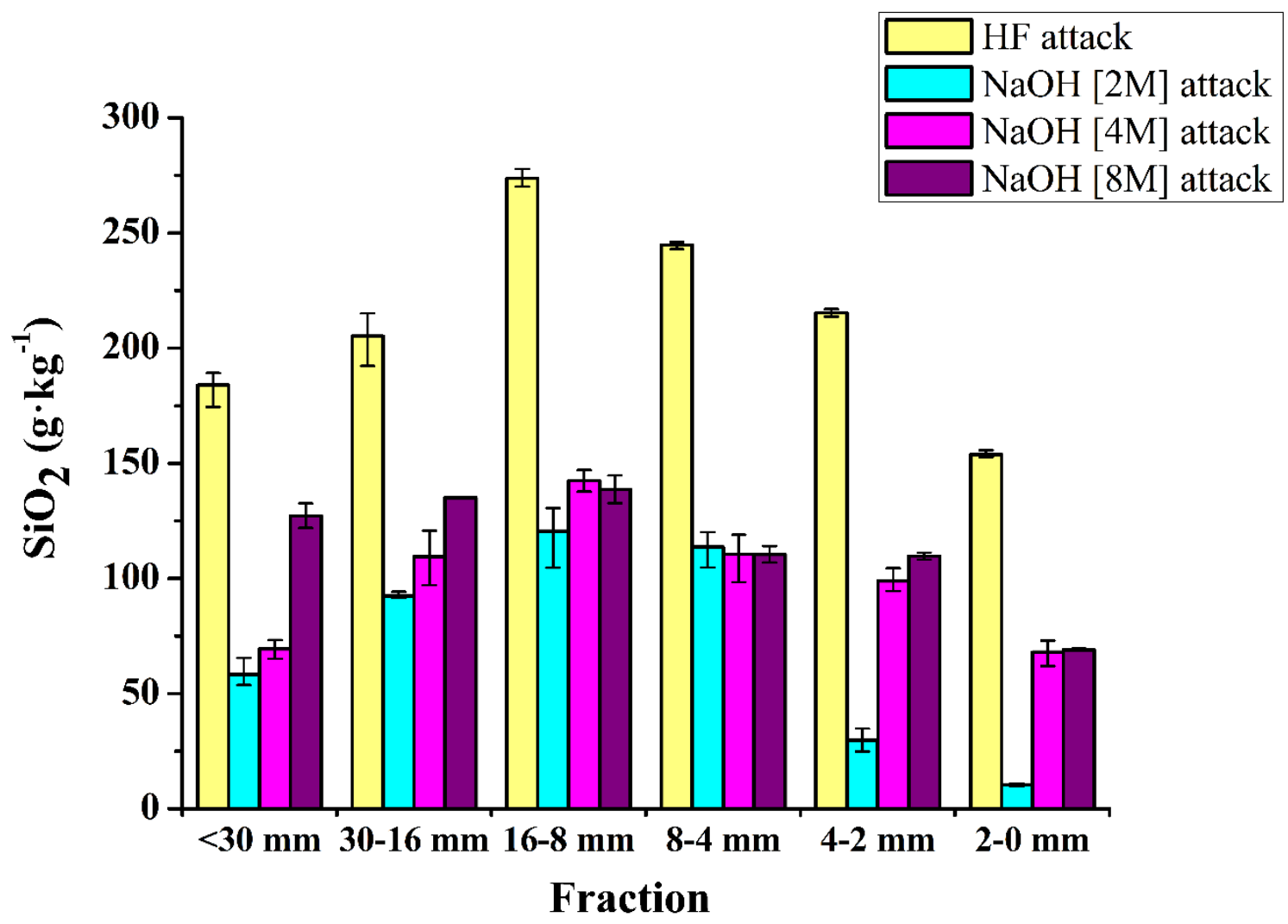

Fig. 4. $\mathrm{SiO}_{2}$ availability of WBA as a function of particle size fraction and chemical attack solution.

Fig. 5 shows the percentage of $\mathrm{SiO}_{2}$ extracted from the $\mathrm{NaOH}$ chemical attacks as a function of the $\mathrm{SiO}_{2}$ extracted from HF chemical attack (thereby assuming that the amount extracted with the $\mathrm{HF}$ attack is $100 \%$ of the $\mathrm{SiO}_{2}$ available in the WBA samples). The results show that it is not possible to extract the same amount of $\mathrm{SiO}_{2}$ with $\mathrm{NaOH}$ as with $\mathrm{HF}$ chemical attacks, at least not under the experimental conditions of this study (particle size, $\mathrm{NaOH}$ concentration, agitation, and temperature). 


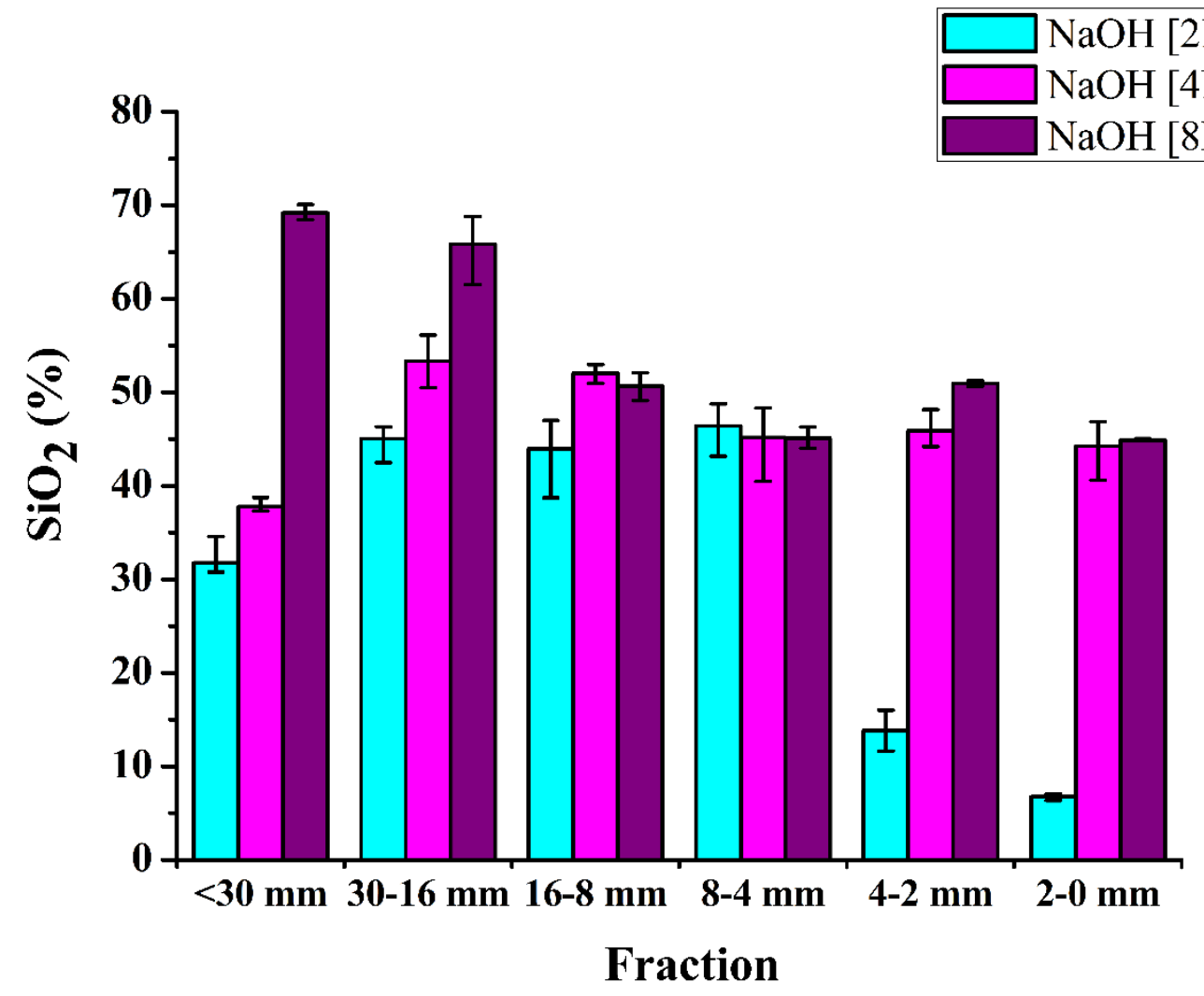

Fig. 5. $\mathrm{SiO}_{2}$ percentage extracted from $\mathrm{NaOH}$ attacks as a function of $\mathrm{HF}$ attack.

The $\mathrm{Al}_{2} \mathrm{O}_{3}$ availability in Fig. 6 shows the same broad trends as in Fig. 4. Considering each particle size fraction, as the $\mathrm{NaOH}$ concentration increases, the $\mathrm{Al}_{2} \mathrm{O}_{3}$ availability also increases (except for the 8-4, and 16-8 mm fractions). Regarding the trend for all the fractions as a function of the chemical attack, an inverse curve to that observed in Fig. 4 is the result, with the minimum value for the $16-8 \mathrm{~mm}$ fraction. Considering each fraction, as $\mathrm{NaOH}$ concentration increases, it is also increasing the $\mathrm{Al}_{2} \mathrm{O}_{3}$ availability (except for the $<30$ and $8-4$ $\mathrm{mm}$ fractions). The main reason for the high $\mathrm{Al}_{2} \mathrm{O}_{3}$ availability in the finest fractions is that the Eddy current equipment only separates fractions above $10 \mathrm{~mm}$, as mentioned previously. Hence, the aluminium content in fractions below $10 \mathrm{~mm}$ is high. The low $\mathrm{Al}_{2} \mathrm{O}_{3}$ availability in coarse fractions is due to the high content of synthetic ceramics, which implies more $\mathrm{Al}_{2} \mathrm{O}_{3}$ crystalline phases. The results obtained with the HF chemical attack are not shown, since this solution does not contribute to the extraction of the reactive $\mathrm{Al}_{2} \mathrm{O}_{3}$ phases. 


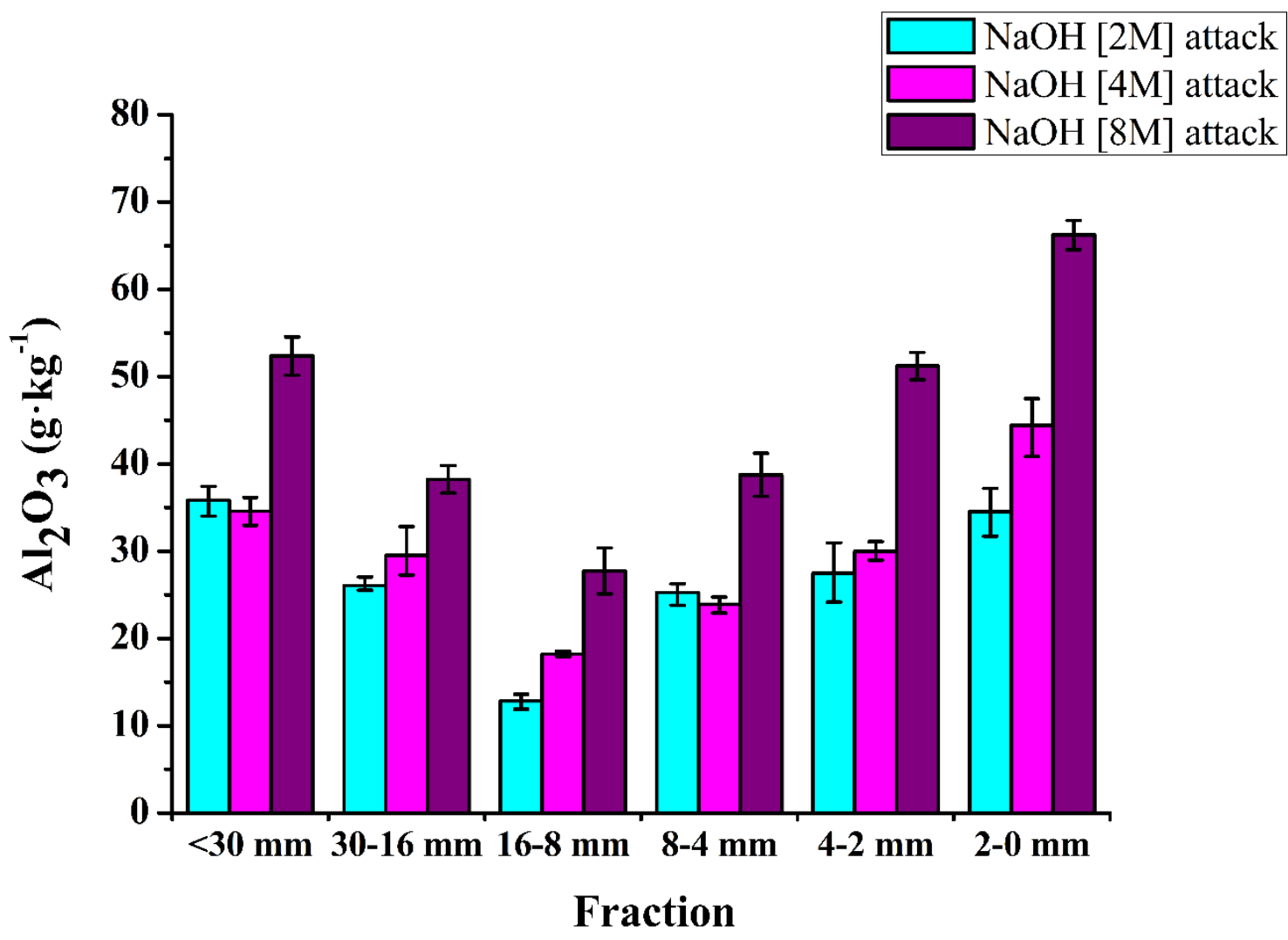

\section{Fig. 6. $\mathrm{Al}_{2} \mathrm{O}_{3}$ availability of $\mathrm{WBA}$ as a function of particle size fraction and chemical attack solution.}

Considering the $\mathrm{SiO}_{2}$ and $\mathrm{Al}_{2} \mathrm{O}_{3}$ availability the $\mathrm{SiO}_{2} / \mathrm{Al}_{2} \mathrm{O}_{3}$ ratio was obtained, as shown in Fig. 7. Taking into account that several authors consider the optimal $\mathrm{SiO}_{2} / \mathrm{Al}_{2} \mathrm{O}_{3}$ ratio for AACs to be around 2 (Duxson et al., 2005), this matches with the $<30 \mathrm{~mm}$ fraction (for all the $\mathrm{NaOH}$ chemical attacks), the 4-2 mm fraction (for $\mathrm{NaOH} 8 \mathrm{M}$ ), the $8-4 \mathrm{~mm}$ fraction (for $\mathrm{NaOH} 8 \mathrm{M}$ ), and the 2-0 mm fraction (for $\mathrm{NaOH} 4 \mathrm{M}$ ). It should be emphasised that the other fractions need an additional source of $\mathrm{Al}_{2} \mathrm{O}_{3}$ or $\mathrm{SiO}_{2}$, depending on their content of $\mathrm{SiO}_{2}$ or $\mathrm{Al}_{2} \mathrm{O}_{3}$, respectively. Considering the high $\mathrm{Al}_{2} \mathrm{O}_{3}$ availability in the finest fractions and the high $\mathrm{SiO}_{2}$ availability in coarser fractions, it is expected the best results for the $<30$ $\mathrm{mm}$ fraction. This fraction presents the required ratio between the available $\mathrm{SiO}_{2}$ and $\mathrm{Al}_{2} \mathrm{O}_{3}$ content. 


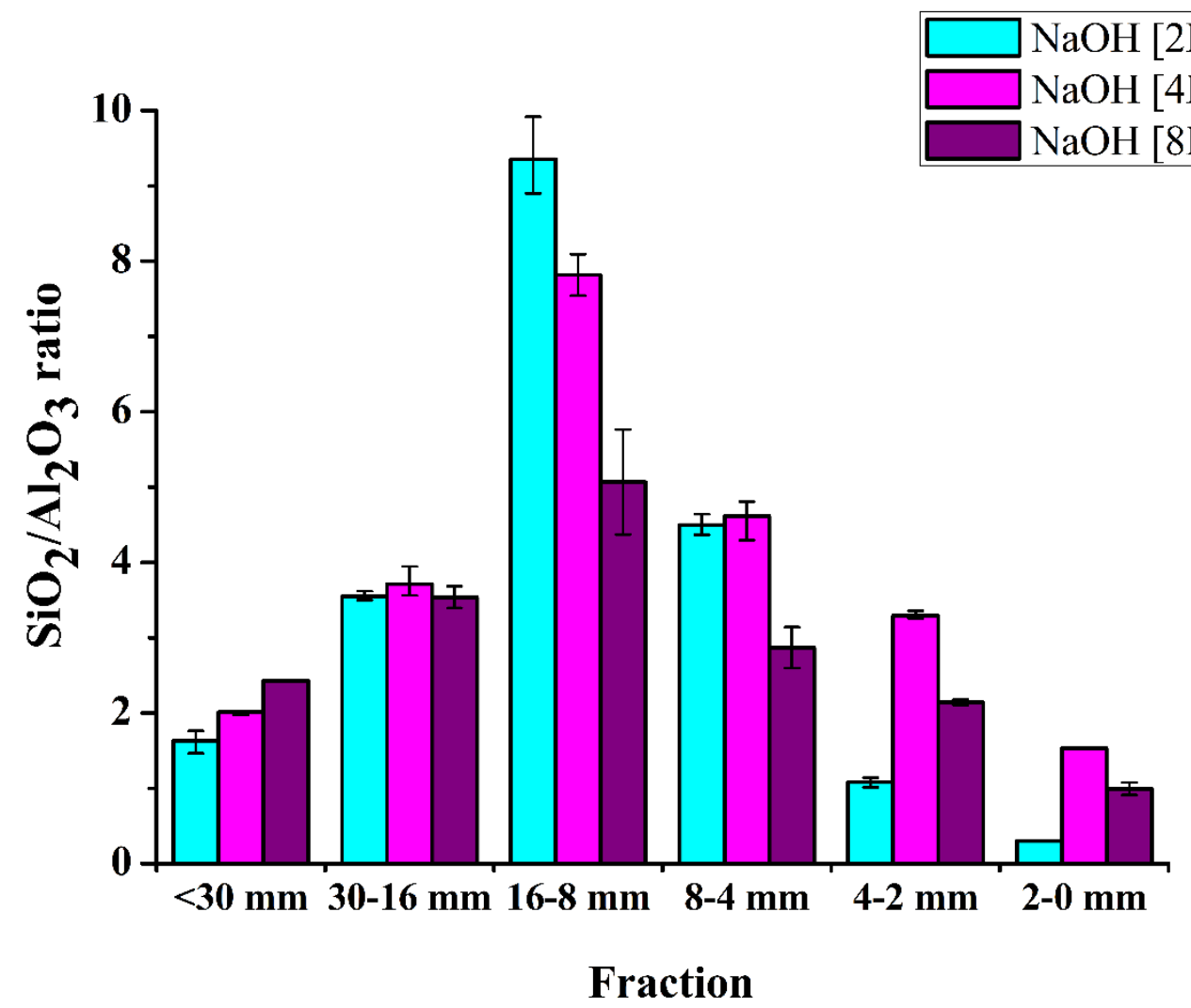

\section{Fig. 7. Si/Al ratio of WBA as a function of particle size fraction and chemical attack solution.}

The initial WBA FT-IR spectra for each fraction were compared to the FT-IR spectra of the attacked WBA in order to evaluate changes in its structure and composition after the chemical attacks. Fig. 8 depicts the FT-IR spectra of the initial WBA samples, according to particle size fraction. The predominant peaks observed in the spectra are typical of carbonate and silicate compounds (Criado et al., 2005). On the one hand, there is a strong band at 1429 $\mathrm{cm}^{-1}$, assigned to the stretching mode of carbonates, as well as sharp peaks at $875 \mathrm{~cm}^{-1}$ and $714 \mathrm{~cm}^{-1}$ related to the bending mode of carbonates. On the other hand, there is a broad band at $1000 \mathrm{~cm}^{-1}$ ascribed to $\mathrm{T}-\mathrm{O}$ stretching vibrations (where $\mathrm{T}=\mathrm{Si}$ or $\mathrm{Al}$ ), and a weak double peak at $780 \mathrm{~cm}^{-1}$ associated with $\mathrm{Si}-\mathrm{O}-\mathrm{Si}$ bridging bonds in quartz $\left(\mathrm{SiO}_{2}\right)$ (Criado et al., 2005). It can be observed a broad shoulder around $980 \mathrm{~cm}^{-1}$ related to $\mathrm{Si}(\mathrm{Al})-\mathrm{O}$ asymmetrical vibrations. The FT-IR results validate those of the XRF and XRD analysis, where $\mathrm{Si}$ and $\mathrm{Al}$ 
were determined as major elements and some alumino-silicate compounds were also identified.

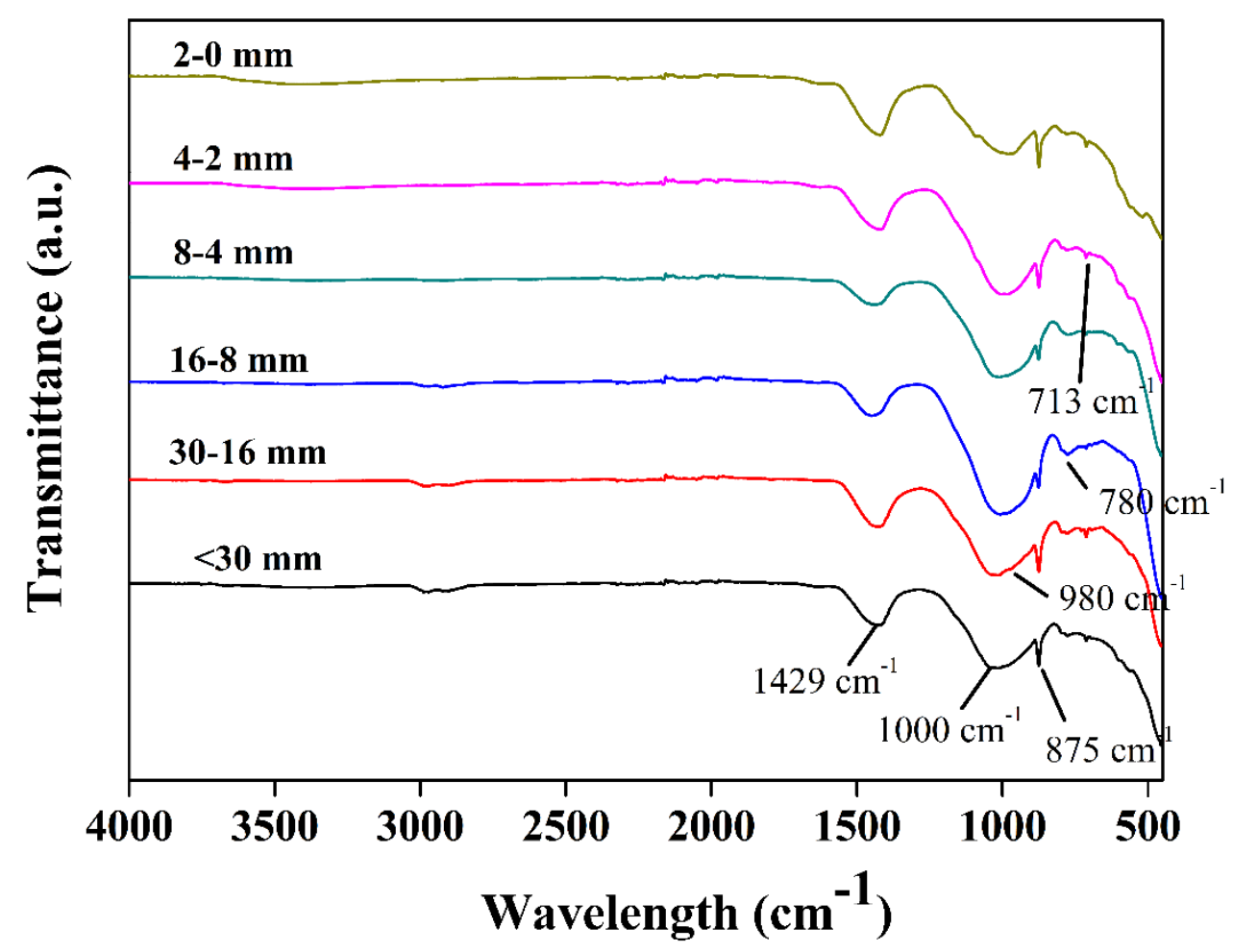

Fig. 8. FT-IR spectrum of the particle size fractions of WBA.

Fig. 9 shows the FT-IR spectra for all the samples as a function of the chemical attack solution, with remarkable differences between them. If the spectra of the WBA samples attacked by $\mathrm{HF}$ and $\mathrm{NaOH} 8 \mathrm{M}$ solutions are compared with the FT-IR spectrum of the initial WBA samples, a great reduction (slightly pronounced in HF) of the Si-O-Si peak can be observed. The spectra of the WBA samples attacked with $\mathrm{NaOH} 2 \mathrm{M}$ and $\mathrm{NaOH} 4 \mathrm{M}$ presents a morphological variation in the Si-O-Si peak compared with the spectrum of the initial WBA samples (a sharpening of the peak at $1000 \mathrm{~cm}^{-1}$ ). These results agree with those obtained in the chemical attacks, where more $\mathrm{SiO}_{2}$ with the $\mathrm{HF}$ and $\mathrm{NaOH} 8 \mathrm{M}$ attacks were extracted than with the $\mathrm{NaOH} 2 \mathrm{M}$ and $\mathrm{NaOH} 4 \mathrm{M}$ attacks, due to the greater aggressiveness of the formers. It also can be observed that the initial carbonate broad band and sharp peaks 
disappear in the $\mathrm{HF}$ chemical attack, in contrast with the $\mathrm{NaOH} 4 \mathrm{M}$ and $\mathrm{NaOH} 8 \mathrm{M}$ solutions,

$\mathbf{a}$

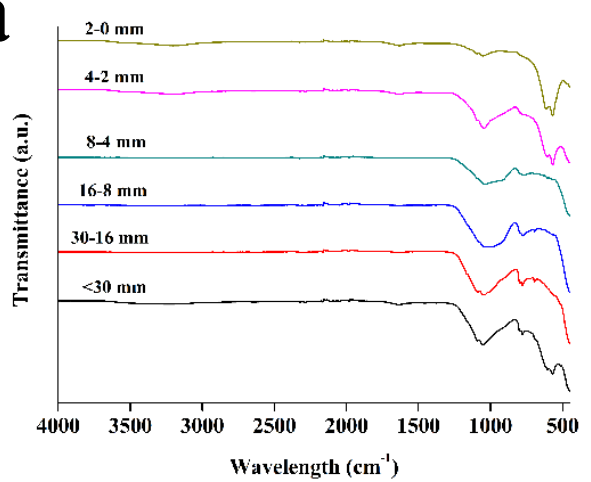

C

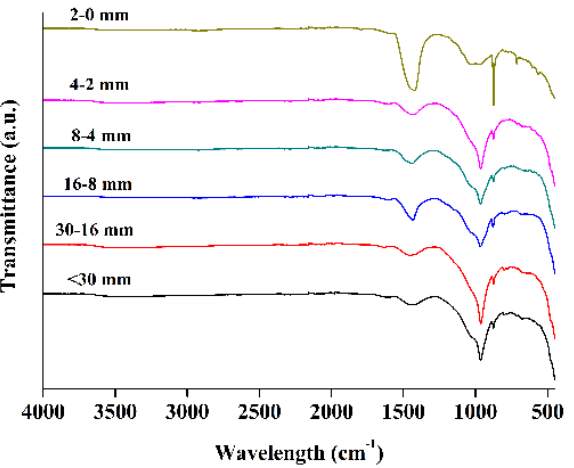

b

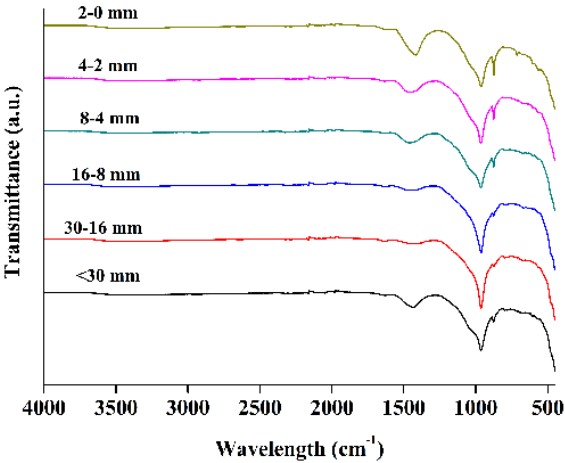

d

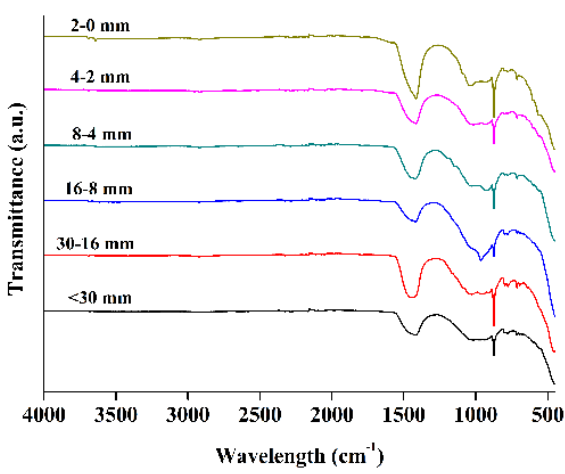

Fig. 9. FT-IR spectra of attacked WBA samples as a function of chemical attack solution (a) $\mathrm{HF}$ (b) $\mathrm{NaOH} 2 \mathrm{M}$ (c) $\mathrm{NaOH} 4 \mathrm{M}$ (d) $\mathrm{NaOH} \mathrm{8M}$ 


\subsubsection{Heavy metals content}

An environmental characterisation of the WBA was performed to evaluate the potential release of metal(loid)s. The study was only conducted for the worst-case scenario, corresponding to the use of the most aggressive reactive alkaline solution (i.e. $\mathrm{NaOH} 8 \mathrm{M}$ ). The heavy metal(loid)s content $\left(\mathrm{mg} \cdot \mathrm{kg}^{-1}\right)$ is shown in Table 4 . The results demonstrate that the WBA samples release more metal(loid)s with an excess of $\mathrm{NaOH} 8 \mathrm{M}$. This means that the alkaline nature of $\mathrm{NaOH} 8 \mathrm{M}$ caused a severe activation of heavy metal(loid)s, because of the high $\mathrm{pH}$ value obtained, since the initial WBA is considered a non-hazardous material (GiroPaloma et al., 2017a; Valle-zermeño et al., 2017). However, it is expected that with the formulation of AAC using WBA as precursor, most of the activated metalloids will remain encapsulated (Kupwade-Patil et al., 2014).

Table 4. Metal(loid)s content of WBA $\left(\mathrm{mg} \cdot \mathrm{kg}^{-1}\right)$ samples.

\begin{tabular}{cccccccccc}
\hline Fraction & $\mathrm{As}$ & $\mathrm{Ba}$ & $\mathrm{Cr}$ & $\mathrm{Cu}$ & $\mathrm{Hg}$ & $\mathrm{Mo}$ & $\mathrm{Ni}$ & $\mathrm{Pb}$ & $\mathrm{Zn}$ \\
\hline$<30 \mathrm{~mm}$ & 6.06 & 294.58 & 23.39 & 23.87 & 0.05 & 14.84 & 8.04 & 133.30 & 896.00 \\
$>16 \mathrm{~mm}$ & 16.77 & 196.98 & 35.65 & 13.44 & 0.16 & 16.72 & 8.24 & 582.07 & 454.70 \\
$16-8 \mathrm{~mm}$ & 12.71 & 385.89 & 10.31 & 18.95 & 0.28 & 16.59 & 8.99 & 477.00 & 325.18 \\
$8-4 \mathrm{~mm}$ & 8.80 & 536.79 & 19.98 & 26.79 & - & 16.90 & 6.58 & 156.68 & 2209.05 \\
$4-2 \mathrm{~mm}$ & 16.05 & 474.21 & 16.43 & 48.17 & - & 18.60 & 9.13 & 736.89 & 1710.49 \\
$2-0 \mathrm{~mm}$ & 8.82 & 408.09 & 18.41 & 77.63 & 0.07 & 17.72 & 8.48 & 433.43 & 4187.92 \\
\hline
\end{tabular}

\section{Conclusions}

It is necessary to find a solution to valorise the large amount of MSWI bottom ash produced around the world and especially in Europe, to promote the new environmental policies of the EU. The research reported herein demonstrates the potential of WBA for use as a precursor in the alkali-activation of cements. Physicochemical characterisation determined the composition based on aluminosilicates and the amorphous nature of WBA samples. The chemical attacks results showed that the $\mathrm{SiO}_{2}$ and $\mathrm{Al}_{2} \mathrm{O}_{3}$ reactive phases are available in each particle size fraction of the WBA. The calculated Si/Al ratio of each WBA sample suggests the possibility of formulating AACs using WBA as sole precursor, or mixed with others, in order to adjust the $\mathrm{Si} / \mathrm{Al}$ ratio to around 2. The environmental characterisation of WBA 
samples showed a high activation of heavy metal(loid)s, due to the redissolution of the $\mathrm{pH}$ dependent metal(loid)s in high $\mathrm{pH}$ media, generated by the alkaline reactive solutions.

The investigation future line will be based on the formulation of AACs using WBA as only precursor. The main goal must be valorising the maximum amount of WBA (using >30 $\mathrm{mm}$ sample or mixing some fractions) without affecting to the AACs environmental properties. It will certainly be necessary to study the release of heavy metals and metal(loid)s from new AACs developed using WBA as a precursor to elucidate if it means a limitation on the final environmental properties of the materials. It is expected that to obtain AACs, there will be less release due to the encapsulation of metal(loid)s in the binder matrix and a decrease of the permeability of leaching solutions. Otherwise, WBA will be mixed with other more noble precursors in order to dilute the concentration of the heavy metal(loid)s content.

\section{Acknowledgements}

The work is partially funded by the Spanish Government (BIA2017-83912-C2-1-R). The authors would like to thank the Catalan Government for the quality accreditation given to their research groups DIOPMA (2017 SGR 118). The authors also want to thank SIRUSA and VECSA for supplying MWI Bottom Ash. Mr. Alex Maldonado-Alameda is grateful to the Government of Catalonia for the research Grant (FI-DGR 2017).

\section{References}

Aljerf, L., 2015. Effect of Thermal-cured Hydraulic Cement Admixtures on the Mechanical Properties of Concrete. Interceram - Int. Ceram. Rev. 64, 346-356. https://doi.org/10.1007/BF03401142

Alonso, S., Vázquez, T., Puertas, F., Martínez-Ramírez, S., 2000. Alkali-activated fly ash / slag cement Strength behaviour and hydration products. Cem. Concr. Res. 30, 16251632. https://doi.org/10.1016/S0008-8846(00)00298-2

Arm, M., 2003. Mechanical properties of residues as unbound road materials - experimental 
tests on MSWI bottom ash, crushed concrete and blast furnace slag.

Bakharev, T., 2005. Resistance of geopolymer materials to acid attack. Cem. Concr. Res. 35, 658-670. https://doi.org/10.1016/j.cemconres.2004.06.005

Bernal, S.A., Rodríguez, E.D., Kirchheim, A.P., Provis, J.L., 2016. Management and valorisation of wastes through use in producing alkali-activated cement materials. J. Chem. Technol. Biotechnol. 91, 2365-2388. https://doi.org/10.1002/jctb.4927

CEWEP, 2016. Bottom ash fact sheet.

Chen, I.A., 2009. Synthesis of Portland Cement and Calcium Sulfoaluminate-Belite Cement for Sustainable Development and Performance. PCA R\&D Ser. No. SN3130 1-216.

Cheng, H., Hu, Y., 2010. Municipal solid waste (MSW) as a renewable source of energy: Current and future practices in China. Bioresour. Technol. 101, 3816-3824. https://doi.org/10.1016/j.biortech.2010.01.040

Chimenos, J.., Segarra, M., Fernández, M.., Espiell, F., 1999. Characterization of the bottom ash in municipal solid waste incinerator. J. Hazard. Mater. 64, 211-222. https://doi.org/10.1016/S0304-3894(98)00246-5

Chimenos, J.M., Fernández, A.I., Miralles, L., Segarra, M., Espiell, F., 2003. Short-term natural weathering of MSWI bottom ash as a function of particle size. Waste Manag. 23, 887-895. https://doi.org/10.1016/S0956-053X(03)00074-6

Chimenos, J.M., Fernandez, A.I., Nadal, R., Espiell, F., 2000. Short term natural weathering of MSWI bottom ash. J. Hazard. Mater. B79 79, 287-299.

Cioffi, R., Colangelo, F., Montagnaro, F., Santoro, L., 2011. Manufacture of artificial aggregate using MSWI bottom ash. Waste Manag. 31, 281-288. https://doi.org/10.1016/j.wasman.2010.05.020

Criado, M., Palomo, A., Fernández-Jiménez, A., 2005. Alkali activation of fly ashes. Part 1: Effect of curing conditions on the carbonation of the reaction products. Fuel 84, 2048 
2054. https://doi.org/10.1016/j.fuel.2005.03.030

Duxson, P., Fernández-Jiménez, A., Provis, J.L., Lukey, G.C., Palomo, A., Van Deventer, J.S.J., 2007. Geopolymer technology: The current state of the art. J. Mater. Sci. 42, 2917-2933. https://doi.org/10.1007/s10853-006-0637-z

Duxson, P., Provis, J.L., Lukey, G.C., Mallicoat, S.W., Kriven, W.M., Van Deventer, J.S.J., 2005. Understanding the relationship between geopolymer composition, microstructure and mechanical properties. Colloids Surfaces A Physicochem. Eng. Asp. 269, 47-58. https://doi.org/10.1016/j.colsurfa.2005.06.060

European Commision, 2015. Directive of the European Parlament and of the Council amending Directive 94/62/EC on packaging and packaging waste.

https://doi.org/10.1007/s13398-014-0173-7.2

European Commission, 2017. Report from the commission to the european parliament, the council, the european economic and social committee and the committee of the regions. Off. J. Eur. Union COM(2017), 1-14.

European Parliament and Council, 2008. Directive 2008/98/EC of the European Parliament and of the Council of 19 November 2008 on waste and repealing certain directives. Off. J. Eur. Union 3-30. https://doi.org/2008/98/EC.; 32008L0098

Ginés, O., Chimenos, J.M., Vizcarro, A., Formosa, J., Rosell, J.R., 2009. Combined use of MSWI bottom ash and fly ash as aggregate in concrete formulation: Environmental and mechanical considerations. J. Hazard. Mater. 169, 643-650. https://doi.org/10.1016/j.jhazmat.2009.03.141

Giro-Paloma, J., Maldonado-Alameda, A., Formosa, J., Barbieri, L., Chimenos, J.M., Lancellotti, I., 2017a. Geopolymers based on the valorization of Municipal Solid Waste Incineration residues, in: IOP Conference Series: Materials Science and Engineering. https://doi.org/10.1088/1757-899X/251/1/012125 
Giro-Paloma, J., Ribas-Manero, V., Maldonado-Alameda, A., Formosa, J., Chimenos, J.M., 2017b. Use of municipal solid waste incineration bottom ash and crop by-product for producing lightweight aggregate, in: IOP Conference Series: Materials Science and Engineering. https://doi.org/10.1088/1757-899X/251/1/012126

Hjelmar, O., Holm, J., Crillesen, K., 2007. Utilisation of MSWI bottom ash as sub-base in road construction: First results from a large-scale test site. J. Hazard. Mater. 139, 471480. https://doi.org/10.1016/j.jhazmat.2006.02.059

Jansen, D., Stabler, C., Goetz-Neunhoeffer, F., Dittrich, S., Neubauer, J., 2011. Does

Ordinary Portland Cement contain amorphous phase? A quantitative study using an external standard method. Powder Diffr. 26, 31-38. https://doi.org/10.1154/1.3549186

Johansson, I., Bavel, B. Van, 2003. Polycyclic aromatic hydrocarbons in weathered bottom ash from incineration of municipal solid waste. Chemosphere 53, 123-128. https://doi.org/10.1016/S0045-6535(03)00299-6

Komnitsas, K.A., 2011. Potential of geopolymer technology towards green buildings and sustainable cities. Procedia Eng. 21, 1023-1032. https://doi.org/10.1016/j.proeng.2011.11.2108

Kupwade-Patil, K., Allouche, E.N., Islam, R., Gunasekaran, A., 2014. Encapsulation of solid waste incinerator ash in geopolymer concretes and its applications. ACI Mater. J. 111, 691-700. https://doi.org/10.14359/51686834

Lancellotti, I., Ponzoni, C., Bignozzi, M.C., Barbieri, L., Leonelli, C., 2014. Incinerator bottom ash and ladle slag for geopolymers preparation. Waste and Biomass Valorization 5, 393-401. https://doi.org/10.1007/s12649-014-9299-2

Magnusson, Y., 2005. Environmental Systems Analysis for utilisation of bottom ash in ground constructions. Trita-KET-IM.

McLellan, B.C., Williams, R.P., Lay, J., Van Riessen, A., Corder, G.D., 2011. Costs and 
carbon emissions for geopolymer pastes in comparison to ordinary portland cement. J. Clean. Prod. 19, 1080-1090. https://doi.org/10.1016/j.jclepro.2011.02.010

Murri, A.N., Rickard, W.D.A., Bignozzi, M.C., Riessen, A. Van, 2013. High temperature behaviour of ambient cured alkali-activated materials based on ladle slag. Cem. Concr. Res. 43, 51-61. https://doi.org/10.1016/j.cemconres.2012.09.011

Pecqueur, G., Crignon, C., Que, B., 2001. Behaviour of cement-treated MSWI bottom ash 21, 229-233.

Pérez-Martínez, S., Giro-paloma, J., Maldonado-alameda, A., Formosa, J., Queralt, I., 2019. Characterisation and partition of valuable metals from WEEE in weathered municipal solid waste incineration bottom ash, with a view to recovering 218, 61-68. https://doi.org/10.1016/j.jclepro.2019.01.313

Phair, J.W., 2006. Green chemistry for sustainable cement production and use. Green Chem. 8, 763-780. https://doi.org/10.1039/b603997a

Roy, D.M., 1999. Alkali-activated cements: Opportunities and challenges. Cem. Concr. Res. 29, 249-254. https://doi.org/10.1016/S0008-8846(98)00093-3

Ruiz-Santaquiteria, C., Fernándes-Jiménez, a, Palomo, a, 2011. Quantitative determination of reactive $\mathrm{SiO} 2$ and $\mathrm{Al} 2 \mathrm{O} 3$ in aluminosilicate materials. 13th Int. Congr. Chem. Cem. $1-7$.

Shim, Y., Kim, Y., Kong, S., Rhee, S., Lee, W., 2003. The adsorption characteristics of heavy metals by various particle sizes of MSWI bottom ash. Waste Manag. 23, 851-857. https://doi.org/10.1016/S0956-053X(02)00163-0

Silva, R. V., de Brito, J., Lynn, C.J., Dhir, R.K., 2017. Use of municipal solid waste incineration bottom ashes in alkali-activated materials, ceramics and granular applications: A review. Waste Manag. 68, 207-220. https://doi.org/10.1016/j.wasman.2017.06.043 
Singh, B., G., I., Gupta, M., Buattacharyya, S.K., 2015. Geopolymer Concrete : A Review of some recent developments. Constr. Build. Mater. 85, 78-90.

Snellings, R., Salze, A., Scrivener, K.L., 2014. Use of X-ray diffraction to quantify amorphous supplementary cementitious materials in anhydrous and hydrated blended cements. Cem. Concr. Res. 64, 89-98. https://doi.org/10.1016/j.cemconres.2014.06.011

Toraldo, E., Saponaro, S., Careghini, A., Mariani, E., 2013. Use of stabilized bottom ash for bound layers of road pavements. J. Environ. Manage. 121. https://doi.org/10.1016/j.jenvman.2013.02.037

Valle-zermeño, R., Formosa, J., Chimenos, J.M., 2017. Material characterization of the MSWI bottom ash as a function of particle size . Effects of glass recycling over time. Sci. Total Environ. 581-582, 897-905. https://doi.org/10.1016/j.scitotenv.2017.01.047 Van Deventer, J.S.J., Provis, J.L., Duxson, P., 2012. Technical and commercial progress in the adoption of geopolymer cement. Miner. Eng. 29, 89-104.

https://doi.org/10.1016/j.mineng.2011.09.009

Wei, Y., Shimaoka, T., Saffarzadeh, A., Takahashi, F., 2011. Mineralogical characterization of municipal solid waste incineration bottom ash with an emphasis on heavy metalbearing phases. J. Hazard. Mater. 187, 534-543. https://doi.org/10.1016/j.jhazmat.2011.01.070

Yao, W.J., Fan, L., Liu, G.Y., 2018. Properties of Alkali-Activated Waste Glass-Cement Cementitious Materials. Mater. Sci. Forum 926, 134-139. https://doi.org/10.4028/www.scientific.net/MSF.926.134

Zhang, H., Shimaoka, T., 2013. Formation of Humic Substances in Weathered MSWI Bottom Ash. Sci. World J. 2013. 